\title{
Education and Power: Republican Ideology and its Educational Policy
}

\author{
Assist. Prof. Dr. Erinç Erdal Yı1dırım \\ Bülent Ecevit University, Zonguldak/TURKEY
}

\begin{abstract}
Early years of Turkish Republic was the period of a nation-state building. Hence, modernization and construction of a new identity -national identity-among the peoples was the core problem of the ruling cadre. The targeted modernization of the Republic was based on transforming the empire to a nation-state by way of constructing modern social and political institutions. From this viewpoint, education became among the significant institutions of the Republic utilized as a tool of transmitting the official ideology to the new generation.

This study aims to put forth the basics of official ideology in Turkey and its reflections on educational practices during early Republic, namely Atatürk Era (1922-1938). In this respect, this study attempted to reveal the educational approach of the ruling cadre and to answer the question of what kind of a citizen was aimed to be raised. In this respect; decisions made by Instruction and Pedagogy Committee as to reflect the policies of the Ministry of Education were examined. Moreover; official speeches, directives and the discussions in the parliament as well as the education congresses held concerning the educational policies and applications were analyzed.
\end{abstract}

Keywords: Early Turkish Republic, Educational Policy, Official Ideology, Nationalism

\section{Introduction}

Education, not only for Turkey, stands out as a pillar that rests over the infrastructure of communities. It is education that gives and guards the identity of states, nations or communities. Policy of the modern state, in almost all societies is extremely influential in education of masses. The ideology of the state directly affects and reflects its philosophy of education. Accordingly, the curricula; aims and content of the courses and sources to be used are determined in line with that philosophy. Ruling classes aim to perpetuate their authorities over educational institutions ${ }^{1}$. In this respect, education becomes the institution -ideological tool- through which political power transfers its values, aims and worldviews to the new generations. In this respect, dominant culture of a society is largely determined by the official ideology, and educational curricula are the fundamental tools of its transmission ${ }^{2}$.

In this study, the period of early Turkish Republic is analyzed basing upon the assumption that, every educational system and process is affected and determined by social, political and economical conditions. Hence, it should be described in relation with the ambient social and political structures. The kind of manpower to be educated, the kind of knowledge to be taught and ideals, values to be transferred are decided and applied in this context ${ }^{3}$. In this respect, this study aims to reveal the educational approach of the ruling cadre and to answer the question of what kind of a citizen was aimed to be raised. In this respect; official speeches, directives and the discussions in the parliament, the education congresses held concerning the educational policies and applications

\footnotetext{
${ }^{1}$ Ephraim V. Sayers, Ward E. Madden, Education and the Democratic Faith: An Introduction to Philosophy of Education, New York: Appleton-Century-Croft, 1959, p.243

${ }^{2}$ As Apple argues in his several writings, school curricula do not serve neutral knowledge; yet the knowledge to be taught is under the domination of the politics. Michael W. Apple, Education and Power, New York: Routledge, 1985; Michael W. Apple, Ideology and Curriculum, New York: Routledge, 1990; Michael W. Apple, Cultural Politics and Education, New York: Teachers College Press, 1996

${ }^{3}$ Kemal İnal, Eğitim ve İktidar: Türkiye'de Ders Kitaplarında Demokratik ve Milliyetçi Değerler, Ankara: Ütopya Yayınevi, 2004, p.12, 39
} 
as well as the decisions made by Instruction and Pedagogy Committee (IPC-Talim ve Terbiye Dairesi) as to reflect the policies of the Ministry of Education ${ }^{4}$ were analyzed.

\section{Constructing National Identity during Early Republican Period}

One of the radical changes the First World War entailed was the collapse of European Empires. Among them was the Ottoman Empire which, with the effect of nationalist movements among its different elements gave way to Turkish nationalism, leading to the foundation of the Turkish Republic in 1923. Emergence of the Turkish Republic encompassed building of a new, secular nation-state from the heritage of the empire and modernization of the society through radical reforms. Hence, educational policies of the new Republic can only be understood within the context of this modernization and nation-building process. Throughout this process, education became the institution of the Republic utilized as a tool of transmitting the official ideology to the new generation.

One of the prominent aims of the ruling cadre was to install national identity and consciousness among the people of the new Republic. The question of "who is a Turk?" was the core issue of the ruling elite during foundation process and debates continued even in the 1930s. Turkish identity is formulated as an eclectic combination of French territorial model and German ethno-culturalist nationalism. In this respect, while the official discourse was based on citizenship and territorial belonging, which was stated in the $88^{\text {th }}$ article of the 1924 Constitution, as "People of Turkey is called as Turk in terms of citizenship regardless of their religious and racial differences." understanding of nationalism which was fed from historicist-culturist-ethnicist understanding of central and eastern European romantic nationalist movement. Kemalist perception of nation can be best observed in the book titled Vatandaş için Medeni Bilgiler (Civil Knowledge) which was written in 1930 by Afet (İnan). The book was also designed as Yurt Bilgisi (Civics), a textbook for civics courses offered in secondary schools. In the book, "nation" is described as "the people of Turkey founding Turkish Republic is called Turkish nation" 6 and the factors which compose Turkish nation include 'unity in race and origin' as well as unity in political existence, language, homeland and also historical and ethnical affinity ${ }^{7}$.

Atatürk targeted to raise the Turkish Republic to the "level of contemporary civilizations". The plan was to modernize not only the state, but the entire society in order to 'progress'. Modernization through westernization was the core of Kemalism and in this context positivism was the basic characteristic of this modernization project $^{8}$. Inspired by Enlightenment, accepting superiority of reason and positive science instead of religiousmetaphysic thought and emphasis on temporality was a very important part of this movement. Therefore the reforms aimed to limit the sphere of religion into the domains of the individuals.

\section{Education for the Modernization of the New Republic}

Characteristics of political transformation were soon reflected to the educational system and the Republican cadre aimed to transfer basics of the Revolution through education. The new mentality, viewpoint and spirit

\footnotetext{
${ }^{4}$ IPC, established in 1926 as an organ of the Ministry of Education, played a significant role in planning educational policies and curricula. The activities of the IPC were crucial in formulating and disseminating the Kemalist ideology via education. Composed of prominent members of the Republican educational elite, the Committee undertook critical duties such as determining educational goals and pedagogical obligations, examining existing textbooks and commissioning new ones.

5 Suna Kili, A. Şeref Gözübüyük, Sened-i İttifak’tan Günümüze Türk Anayasa Metinleri, (3rd ed.) İstanbul: Türkiye İş Bankası Kültür Yayınları, 1985, p.147

${ }^{6}$ Afet İnan, Vatandaş İ̧̧in Medeni Bilgiler, İstanbul: Milliyet Matbaası, 1930, p. 16

7 ibid, p.23-24. It should be noted that the definition of Turkish nation and the factors characterizing it might look contradictory at first because of the term race. However, this term was not used with the understanding of a specific and narrow definition of a biological race, but rather referred to a broad-set umbrella identity. In other words, this concept was not based on an exclusionist approach, but adhered to inclusivity in the sense of operating as an assimilationist melting pot.

${ }^{8}$ Taner Timur, Türk Devrimi ve Sonrası, Ankara: İmge, 1993
} 
were transferred to new generations by schools providing education on positivist philosophy ${ }^{9}$. In this political atmosphere, ruling cadre applied a conscious policy of reorganizing the entire education system, expanding it in a systematic way and harnessing it to national goals ${ }^{10}$.

Most of the Turkish and foreign scholars dealing with Turkish educational system were in consensus on education being the key to modernization. They advocated that the ideal and modernization perception of Kemalists focused on abandoning religious dogmas and facing Western mentality instead. Modern Turkish schools of the time helped to socialize the youth with such understanding and served as important nationbuilding agents spreading Republican ideology. Andreas Kazamias, in his work on the role of education in modernizing Turkish society, used the word "modernization" synonymously with Westernization and defined it as the process of transforming Ottoman Islamic institutions, concepts and way of life into a secular constitutional republic ${ }^{11}$.

Unification of Education Law (Tevhid-i Tedrisat Yasast) enacted in May 3, 1924 played a significant role in transition into a modern state and specifically nationalization of education. Yet, before application of this law, Educational Treaty (Misak-ı Maarif) was accepted in March 1923 underlining the necessity of the national, secular and scientific character of education. In this respect, Atatürk made numerous visits to various parts of the country to explain the public the importance of national education which was "deprived of old period's superstitions and thoughts and also the effects of foreign ideas coming from east and west; a culture coherent with our national character and history" ${ }^{\prime 2}$.

The official directives given by the Ministry of Education to the administrators and teachers are important documents to give us an idea about the nature of the Turkish educational system and its practices. For instance, a 1923 document indicated: "Schools ought to inculcate students to become subjects faithful to the principles of the Republic." A 1924 document stated: "In their hearts and souls, our children ought to have the ideal of sacrificing themselves for the Republic, if necessary." and another in 1931 was, "Turkish schools ought to teach psychology and ideology of the Republican regime to every Turkish youngster and prepare them to be most efficient citizens for the Turkish nation and the Republic." 13

As the abovementioned statements point out, modernization and raising nationalist consciousness were the two main pillars of the mission designated for education. By means of the nationwide education campaign, the cadres of the Republic had, on the one hand, endeavored to modernize the country in the Western sense and, on the other hand, to implant a nationalistic consciousness, i.e. "the consciousness of Turkishness" among the new generation. In this regard, the major objective of the new state could be summarized as "implementing new courses and the curricula, teaching methods and techniques in line with contemporary reformist education movements that arose in the West so as to make Turkey "nationalized' as well as 'civilized""14.

Republic's intent of modernization, which can be described as becoming westernized, has inherently driven the ruling cadres to focus on the West's approach towards and practices on education. Therefore, the attempts to adopt western reformist views on education in the West by means of translations and copyrighted works became common practice during this period. Many educators and students benefited from the opinions and suggestions of foreign experts ${ }^{15}$ invited to Turkey concerning the education system of the country, while many

\footnotetext{
${ }^{9}$ Donald E. Webster, The Turkey of Atatürk; Social Process in the Turkish Reformation, New York: AMS Press, 1973

${ }^{10}$ Joseph S. Szyliowicz, Education and Modernization in the Middle East, Ithaca: Cornell University Press, 1973

${ }^{11}$ Andreas Kazamias, Education and the Quest for Modernity in Turkey, Chicago: University of Chicago Press, 1966, p.115

${ }^{12}$ Atatürk'ün Söylev ve Demeçleri, vol. II, Ankara: TTK, 1959, pp.16-17

${ }^{13}$ Yahya Akyüz, Türkiye'de Öğretmenlerin Toplumsal Değişmedeki Etkileri (1848-1940), Ankara: Doğan Basımevi, 1978, p. 275

${ }^{14}$ Osman Kafadar, Türk Eğitim Düşüncesinde Batılılaşma, Ankara: Vadi Yayınları, 1997, p. 155

${ }^{15}$ In this respect, Republican educators adopted from Euro-American pedagogic spheres; 'learning by doing' and looking upon schools as 'miniature society', rather than 'a stage of preparation for life'. Barak Salmoni, "Turkish Knowledge for a Modern Life: Innovative Pedagogy and Nationalist Substance in Primary Schooling, 1927-50”, Turkish Studies, 4 (3), 2003, p. 103-104.
} 
others were sent to different countries ${ }^{16}$ in order to experience the educational practices there and convey their observations upon their return. Prime Minister İnönü's below statements at the Teacher's Union in 1925 clearly demonstrate how they perceived national education:

We want national education. What does this mean? We can better understand it when we define the opposite better: When we are asked about the opposite of national education we say that this is either religious education or international education. The education extended will not be religious or international but it will be national... Our education will be ours and it will be for us... There are Turkish people who give to this land its character. But this nation does not yet display the uniterianism we want... In this unified nation, all foreign cultures should be completely melted... If we are going to live we will live as a unified nation. This is the goal of the system which we call national education ${ }^{17}$

A point that should be mentioned at this juncture is that they perceived the children, i.e. the "soldiers of the Republic", not only as belongings of parents, but also, maybe even more so, of the nation ${ }^{18}$. An emphasis frequently repeated in the speeches of the politicians as well as in the textbooks was that, individuals should love and cherish their country and nation, work for and support them with unconditional priority ${ }^{19}$. Even attending personal hygiene and observing sanitation was evaluated as patrimonial care and devotion ${ }^{20}$. Comprehension of RPP's such understandings makes it possible to claim what lied beneath this perception was solidity of assuming citizenship as individualistic restrictions or sacrifices of personal interests on behalf of country's welfare.

Solidarism was one of the main veins feeding the Republican cadres' understanding of nationalism ${ }^{21}$. Indeed, it is possible to say that nationalism and populism were complementary principles based on solidarism: While nationalism referred to a single Turkish identity in the process of transition from a multi-national empire into nation-state, populism defined this identity as a homogeneous, classless society. The most important factor

These ideas were popularized by John Dewey, American philosopher and educational reformer. He was one of the educationists who were invited to Turkey. For information about the reports of foreign experts indicating their views upon Turkish educational system and their effects on the educational practices, see İlhan Başgöz, Türkiye'nin Eğitim Çıkmazı ve Atatürk, İstanbul: Pan Yayıncılık, 2005

${ }^{16}$ In this context, during 1930s many students from different branches were sent abroad to be trained as secondary and high school teachers. Decision of the Instruction and Pedagogy Comittee, issue 95, 1929; issue 104, 1930; issue 171, 1931. For further information, see Kansu Şarman, Türk Promethe'ler, İstanbul: İş Bankası Kültür Yayınları, 2006

${ }^{17}$ Hasan Ali Yücel, Türkiye’de Ortaöğretim, Ankara: Kültür Bakanlığı Yayınları, 1994, p. 25

18 "23 Nisan Çocuk Bayramında Ankaradaki Merasimde Maarif Vekili Doktor Reşit Galip Beyin Nutku," cited in Özge Ertem, The Republic's Children and Their Burdens in 1930s and 1940s Turkey: The Idealized Middle-Class Children as the Future of the Nation and the Image of "Poor" Children in Children's Periodicals, Unpublished MA Thesis, Boğaziçi University, 2005, p. 44

${ }^{19}$ Expression of the National Anthem everyday by primary grade school children since 1933 with the decision of Commitee of Instruction and Pedagogy serves a good example regarding this issue. Decision of the Instruction and Pedagogy Comittee, issue 101, 1933. As a matter of fact, together with flag ceremonies and commemorations of important historic dates or heroes, this was one of the crucial means of nation-building process in establishing the new regime and adopting it among the new generation. For an extensive information about nationalization of the citizenship through using national symbols in the school curricula, see Jessica S. Tiregol, The Role of Primary Education in Nation-State Building: The Case of the Early Turkish Republic (1923-1938), Unpublished PhD. Thesis, Princeton University, 1998

${ }^{20}$ Hasan Ali Yücel, in one of his parliamentary speeches as the Minister of Education, drew attention to this point while he talked about the ethical maxims that should be followed by Turkish students. Period 6 volume 18 meeting 2, 27.5.1941, Parliamentary Discussions of the Ministry of Education, p. 219-220

${ }^{21}$ As is known, populism which was one of the main components of Turkish modernization was largely formulated on national solidarity. Such a regard of populism was based on Ziya Gökalp's definition, "there are no social classes, but professions acting in solidarity!", and an egalitarian perception of society. This view played a significant part in shaping RPP's perception of society and conveying it to young generations through education. Taha Parla, Ziya Gökalp, Kemalizm ve Türkiye'de Korporatizm, İstanbul: İletişim, 1993 
underlying such a perception particularly with the change in source of legitimacy of sovereignty from divinity to public, was the ultimate need of the Republic for homogeneous, coherent mass and indivisible nation, in which social classes and other differences were reduced to the minimum ${ }^{22}$.

\section{1930s - Unification of the Party Principles With the School Curricula}

1930's were critical years in unification of the state and RPP. In 1930's, the schools became devices for spreading of the RPP ideology; the objectives of the schools outlined in the curriculum guides existed as identical with the principles which appeared in the party program.

The Fourth General Congress of the RPP which convened in Ankara in 1935 constitutes a good example for this. This congress adopted a decision which would give a direction to the training of the new generations, stating; "The most important issue at every level of schooling is to educate Turkish citizens to become firm republican, nationalist, populist, etatist, secularist and revolutionary individuals." 23 Although some changes such as introducing 'modern pedagogical principles into schools' were outlined in the curriculum guides by the Ministry of Education, these changes were in reality the inclusion of political ideologies of the RPP to school curricula.

The above-mentioned qualifications were significant since they referred to the core principles of Kemalism the official ideology of the Republic- namely six arrows as well. In this manner, the Primary Schools Curriculum of 1936 is a striking indicative demonstrating the values new generations are to be brought up with. The chapter on objectives of the 1936 curriculum in accordance with the RPP ideology and its view on education were altered to verify that children will be brought up according to the principles of the $\mathrm{RPP}^{24}$. As a matter of fact, it was included in the new program that these principles had become the fundamentals of the republican regime and in the chapter on "The Objectives of the Primary School" of the 1936 Primary School Curriculum, it was underlined with the following statement that the new generations were also to be trained accordingly:

Primary school should inculcate a national education to the children. The new values that will be made the common property of the Turkish nation through primary school education are the fundamental principles of the regime on culture, which are set out in the chapter of Republican People's Party's program on national education... Attention will be given at all levels of education to raising strong Republican, nationalistic, populist, etatist, secularist and revolutionary citizens. ${ }^{25}$

\section{5. "New Citizen" of the New Regime - National and Moral Education Understanding of the Republic}

The understanding that children of the Republic, as the adults of tomorrow, were expected to inherit fundamental values of the state and convey them in the future is worth special attention. This perception regarded raising mentally and physically well-fit youngsters equipped with high, sturdy moral values utterly important. In this context it is possible to explain the educational understanding of RPP as "national education" and "moral education". In this regard, the emphasis on "raising morally justified, spiritually and physically sound citizens loyal to their country, nation and the principles of the Republic" is frequently repeated in both education curricula and regulations, and orations of the politicians ${ }^{26}$.

\footnotetext{
${ }^{22}$ Asım Karaömerlioğlu, “Tek Parti Döneminde Halkçılık”, Toplum ve Bilim, 88, 2001, p. 175-176

${ }^{23}$ CHP Programı, Partinin Dördüncü Büyük Kurultayı Onaylamıştır, Mayıs 1935, Ankara: Ulus Basımevi, 1935, p 16.

${ }^{24}$ İlhan Başgöz, Türkiye'nin Eğitim Çıkmazı, p.124

${ }^{25} 1936$ İlkokul Programı, İstanbul: Devlet Basımevi, 1936

${ }^{26}$ Even in 1930's, that among the requirements for the students to be sent abroad for training as secondary and high school teachers were more particularly "strong national character and moral", "perfectly healthy, physically and psychologically strong", again reflects the importance the ruling cadre attributes to physical and moral manners. Decision of the Instruction and Pedagogy Comittee, issue 112, 1932. For more information about the discourse of ruling cadre, party programmes,
} 
Atatürk in the speeches he delivered at the Teacher's Union Congress, in 1924, had already requested from the teachers to bring up "mentally, scientifically and physically strong guards", underlining that physical integrity was essential for being a good soldier and a productive citizen ${ }^{27}$. Accordingly, physical fitness was promoted by giving prominence to physical education courses in the curricula as well as through the other activities carried out at schools. Each province was designated as a physical training region and with the Law on Physical Training adopted in 1938, governors were assigned as the chiefs in charge of physical training in the region'. The same law required the youngsters to participate in physical training and sports activities at sports clubs and groups to be established ${ }^{28}$. Moreover, sports centers or halls were established at schools for various physical activities during spare times. These installations provided students the chance to train themselves according to their choice in athletics, handball, soccer, wrestling, boxing tracking, tennis scouting and at appropriate places and weather, learn swimming, mountain climbing, cycling, motorcycling, sailing etc. ${ }^{29}$

Literature concerning physical activities gives important acknowledgements explaining the importance given to sports and physical training by the Republican cadre was a product of careful considerations in the process of creating the stereotype "new man" for the modern nation-state. Hence, in the Turkey of 1930s and 40 s, sports activities were regarded as indispensable components of forming "new type of citizens" and were made use of improving the health, moral regulations, military alertness of individuals and establishing social control to homogenize and mobilize the population through manipulation of their bodies ${ }^{30}$.

\section{Military Training as a Part of Citizenship Education}

From the Balkan Wars to 1926, physical education courses were actually planned to give military knowledge and were turned into compulsory military science courses after this date. Moreover, they were not limited to giving military science alone but included drillings at military camps which students could participate on a written request made by the Ministry of Education from the Presidency of General Staff ${ }^{31}$.

Scouting activities, which were carried out along with military science and physical education classes were also given great importance during this period. The activities of the scouts were modeled on military practices. Scout attires were similar to army uniforms; their marches were the same as in the army; and they were envisaged to make a salute like the Turkish soldiers ${ }^{32}$.

In history and civics textbooks of the same years, military service was identified as the most sacred of citizens' duties. Likewise, military barracks were also seen as places of civic education. In the "Military Duty" chapter of the book Civic Knowledge for the Citizen, the army is identified as a school and military barracks are specified as educational institutions where the youth is trained and educated on culture ${ }^{33}$. In this respect, one can say that a great deal of significance was attached to military service and it was intertwined with civics education. In the chapter titled "The Turkish Army and National Defense" of the book History 4, military service is labeled

regulations on education and curricula, see İsmail Kaplan, Türkiye'de Milli Eğitim İdeolojisi, İstanbul: İletişim Yayınları, 1999

${ }^{27}$ A striking example of how the republican staff paid special attention to the "strong body" image is that; in 1933, during the contest made for the medal in commemoration of Republic's 10th Anniversary, a medal was refused with the reason that "not strength but weakness was observed on the arm holding the flag, and this side of the printed medal did not truly express Republic's 10th Anniversary". Decision of the Instruction and Pedagogy Comittee, issue 203, 1933

${ }^{28}$ T. C. Maarif Vekilliği, Maarifle İlgili Kanunlar, İstanbul: Maarif Matbaası, 1940

${ }^{29}$ State Archives of Turkish Republic, Instruction and Pedagogy Office 1944, 030.01.90.559.5

${ }^{30}$ Yet, this was not just peculiar to Turkey, but gained popularity around various European countries as a matter of a 'modern nation-state'. For further information, see Yiğit Akın, 'Not Just a Game': Sports and Physical Education in Early Republican Turkey (1923-51), Unpublished MA Thesis, Boğaziçi University, 2003, p. 30

${ }^{31}$ Decision of the Instruction and Pedagogy Comittee, issue 73, 1932

${ }^{32}$ Decision of the Instruction and Pedagogy Comittee, issue 204, 1933

${ }^{33}$ İnan Vatandaş İçin Medeni Bilgiler, p.122-123. 
intrinsically as a national superiority, and it was assumed that each patriotic citizen would possess a soldier spirit identified with love for the country based on moral values such as intelligence, determination and heroism. Furthermore, it is expressed that the Turks through centuries of experiences have developed nationalist qualifications as "the Turkish nation has the most mature spirit of military service among all nations" "34. In this respect, it would not be wrong to say that the military-nation myth has a significant place in the Turkish citizen's cultural codes as the maxim "Every Turkish citizen is born as a soldier and dies as a soldier" was repeated frequently in these books ${ }^{35}$.

One of the underlying factors, which feeds back into this, is the conviction of the political power that the 'warrior spirit', which is the most important characteristic of soldiering, is a significant component of and a source of pride for the Turkish culture. Hence, the new generation should be brought up with this spirit and "the [school] curricula shall be reinforced so as to bring the children's capability of contestation and struggling to the utmost." ${ }^{36}$ Indeed, military service and physical education classes were intermingled and acted together as an important tool for the political power to convey its understanding of morality and ethics to the new generation. The following words of the Minister of Education Hasan Ali Yücel during İnönü period reflect this approach very clearly:

Courses of military service are at the same time physical training classes and we believe that there is a strong interaction between ethical training and national morality... I frankly state that the immoralities our generation and the previous ones heard stories of are extremely reduced in our day, and this can be explained with the prevalence of physical training among the youth in the country. ${ }^{37}$

\section{Conclusion}

Emergence of the Turkish Republic did not encompass only the building of a new nation-state from the heritage of the empire, but it also included modernization of the whole society. During this period, Turkish Republic primarily aimed to break down the old traditional-religious understanding and replace it with a modernist, westernized perspective from the beginning. Education became one of the key instruments in transforming the official ideology and formation of a national identity among the new generations.

However, Atatürk's death and presidency of İsmet İnönü demonstrated certain changes in political arena which also had reflections in educational policies. The period's distinct characteristic of educational policy can be identified as humanism ${ }^{38}$. The Ministry of Education leaded a comprehensive movement including translation and publication activities aiming the adoption of 'humanist spirit' and the civilized mindset through Western and Eastern -including Islamic- literary and philosophical sources. This also demonstrated that the Minister of Education, Hasan Ali Yücel did not focus only on the West as observed in the previous era, but aimed for a synthesis of the East and West as a modernization approach as he stated; "I do not make any distinctions as East and West. If there is a separation in the essence, it's because of the way and method selected. If we did not comprehend with the method of Western mind, we could not find its essence in the Easterner's" ${ }^{39}$.

This shift in the modernization perception and the approach to Ottoman-Islamic past could be explained as follows: These were the years experienced consolidation of the system and gaining of a confidence that the regime was under security. The fear of regression almost disappeared among the ruling elite and opposing views

\footnotetext{
${ }^{34}$ Tarih 4, İstanbul: Devlet Matbaası, 1931, p. 344.

${ }^{35}$ Füsun Üstel, "Makbul Vatandaş"ın Peşinde, İstanbul: İletişim, 2004

${ }^{36}$ Period 6, volume 18 meeting 2, 27.5.1941, Parliamentary Discussions of the Ministry of Education, p. 211

${ }^{37}$ Period 6, volume 18 meeting 2, 27.5.1941, Parliamentary Discussions of the Ministry of Education, p. 219

${ }^{38}$ Humanism was traceable in ancient Greek and Latin civilizations through their literary and philosophical sources; it became a movement shaking the West in later centuries and in Turkey appeared among the Republican elite as interest towards the classical world.
}

39 Mustafa Baydar, "Hasan Ali Yücel Anlatıyor”, Varlık, 419, 1955, p. 6. 
were no longer stigmatized as 'reactionist'. In this socio-political atmosphere, there was no need in introducing Turkish Republic and its constituents as a clear break from the past. In this sense, it would be accurate to define the maneuvers during this era as the attempts for the solution of the old "East-West" question which became a remedy for Turkey's "injured consciences", at least temporarily ${ }^{40}$. Hence, humanist policies paved way to the meeting and synthesis of the past and present and of the East and the West. However, they were unable to prevent reactions during the 1940's towards the cultural-educational policies which in the course of time would be the foundation bricks of Turkish-Islamic Synthesis.

\section{References}

[1] 1936 İlkokul Programi, İstanbul: Devlet Basımevi, 1936

[2] A. İnan, Vatandaş İçin Medeni Bilgiler, İstanbul: Milliyet Matbaası, 1930

[3] Kazamias, Education and the Quest for Modernity in Turkey, Chicago: University of Chicago Press, 1966

[4] Karaömerlioğlu, "Tek Parti Döneminde Halkevleri ve Halkçılık”, Toplum ve Bilim, 88, 2001, pp. 163-187

[5] Atatürk'ün Söylev ve Demeçleri, vol. II, Ankara: TTK, 1959

[6] Salmoni, "Turkish Knowledge for a Modern Life: Innovative Pedagogy and Nationalist Substance in Primary Schooling, 1927-50”, Turkish Studies, 4 (3), 2003, pp. 103-144

[7] CHP Programı, Partinin Dördüncü Büyük Kurultayı Onaylamıştır, Mayıs 1935, Ankara: Ulus Basımevi, 1935

[8] E. Webster, The Turkey of Atatürk; Social Process in the Turkish Reformation, New York: AMS Press, 1973

[9] V. Sayers, W. E. Madden, Education and the Democratic Faith: An Introduction to Philosophy of Education, New York: Appleton-Century-Croft, 1959

[10] Üstel, "Makbul Vatandaş"ın Peşinde, İstanbul: İletişim, 2004

[11] H. Ali Yücel, Türkiye’de Ortaögretim, Ankara: Kültür Bakanlığı Yayınları, 1994

[12] İ. Başgöz, Türkiye’nin Eğitim Çıkmazı ve Atatürk, İstanbul: Pan Yayıncılık, 2005

[13] İ. Kaplan, Türkiye'de Milli Eğitim İdeolojisi, İstanbul: İletişim Yayınları, 1999

[14] J. S. Tiregol, The Role of Primary Education in Nation-State Building: The Case of the Early Turkish Republic (19231938), Unpublished PhD. Thesis, Princeton University, 1998

[15] J. S. Szyliowicz, Education and Modernization in the Middle East, Ithaca: Cornell University Press, 1973

[16] K. Şarman, Türk Promethe'ler, İstanbul: İş Bankası Kültür Yayınları, 2006

[17] K. İnal, Eğitim ve İktidar: Türkiye'de Ders Kitaplarında Demokratik ve Milliyetçi Değerler, Ankara: Ütopya Yayınevi, 2004

[18] M. W. Apple, Cultural Politics and Education, New York: Teachers College Press, 1996

[19] M. W. Apple, Education and Power, New York: Routledge, 1985

[20] M. W. Apple, Ideology and Curriculum, New York: Routledge, 1990; http://dx.doi.org/10.4324/9780203241219

[21] M. Baydar, "Hasan Ali Yücel Anlatıyor", Varlık, 419, 1955

[22] O. Koçak, “1920’lerden 1970’lere Kültür Politikaları”, Modern Türkiye’de Siyasî Düşünce vol: 2 Kemalizm, ed. Ahmet İnsel, İstanbul: İletişim Yayınları, 2001, pp. 370-418

[23] O. Kafadar, Türk Eğitim Düşüncesinde Batılllaşma, Ankara: Vadi Yayınları, 1997

[24] Ö. Ertem, The Republic's Children and Their Burdens in 1930s and 1940s Turkey: The Idealized Middle-Class Children as the Future of the Nation and the Image of "Poor" Children in Children's Periodicals, Unpublished MA Thesis, Boğaziçi University, 2005

[25] S. Kili, A. Şeref Gözübüyük, Sened-i İttifak'tan Günümüze Türk Anayasa Metinleri, (3rd ed.) İstanbul: Türkiye İş Bankası Kültür Yayınları, 1985

[26] Tarih 4, İstanbul: Devlet Matbaası, 1931

[27] T. C. Maarif Vekilliği, Maarifle İlgili Kanunlar, İstanbul: Maarif Matbaası, 1940

[28] T. Parla, Ziya Gökalp, Kemalizm ve Türkiye'de Korporatizm, İstanbul: İletişim, 1993

[29] T. Timur, Türk Devrimi ve Sonrasl, Ankara: İmge, 1993

[30] Y. Akyüz, Türkiye'de Öğretmenlerin Toplumsal Değişmedeki Etkileri (1848-1940), Ankara: Doğan Basımevi, 1978

${ }^{40}$ Orhan Koçak, “1920’lerden 1970’lere Kültür Politikaları”, Modern Türkiye'de Siyasî Düşünce vol: 2 Kemalizm, ed. Ahmet İnsel, İstanbul: İletişim Yayınları, 2001, p.397 
[31] Y. Akın, 'Not Just a Game': Sports and Physical Education in Early Republican Turkey (1923-51), Unpublished MA Thesis, Boğaziçi University, 2003 